\title{
The Pelotas Basin Oil Province Revealed - New Interpretation from Long Offset 2D Seismic Data
}

Scott Bowman ${ }^{1}$, Mike Saunders ${ }^{2}$

${ }^{1}$ Petrodynamics, Inc - Houston, TX, ${ }^{2}$ Spectrum Geo, Inc - Houston, TX

Copyright 2014, SBGf - Sociedade Brasileira de Geofísica.

Este texto foi preparado para a apresentação no VI Simpósio Brasileiro de Geofísica, Porto Alegre, 14 a 16 de outubro de 2014. Seu conteúdo foi revisado pelo Comitê Técnico do VI SimBGf, mas não necessariamente representa a opinião da SBGf ou de seus associados. É proibida a reprodução total ou parcial deste material para propósitos comerciais sem prévia autorização da SBGf.

\section{Abstract}

An updated interpretation of $12 \mathrm{~km}$ offset 2D seismic data has revealed evidence of a working petroleum system in the Pelotas Basin, offshore Brazil. Improved PreSDM imaging and quantitative interpretation using AVO attributes has resulted in a model of the basin that includes a working hydrocarbon system with clearly identifiable direct hydrocarbon indicators.

\section{Introduction}

The Pelotas Basin is an untapped hydrocarbon province comprising a $280,000 \mathrm{~km}^{2}$ passive margin located on the south-east coast of Brazil, bordering Uruguay to the south. Up to 7,000 meter thickness of Cretaceous and Tertiary post-rift siliciclastics have been deposited in the basin, including both Paleocene and Albian source rocks. These source rocks are actively generating hydrocarbons today and there are seismic indications of an active, working petroleum system similar in character to those found in the Niger Delta in West Africa and the basins offshore Mozambique and Tanzania. Recent high quality 2D seismic data has imaged multiple potential reservoirs, traps, source rocks and direct hydrocarbon indicators in the basin.

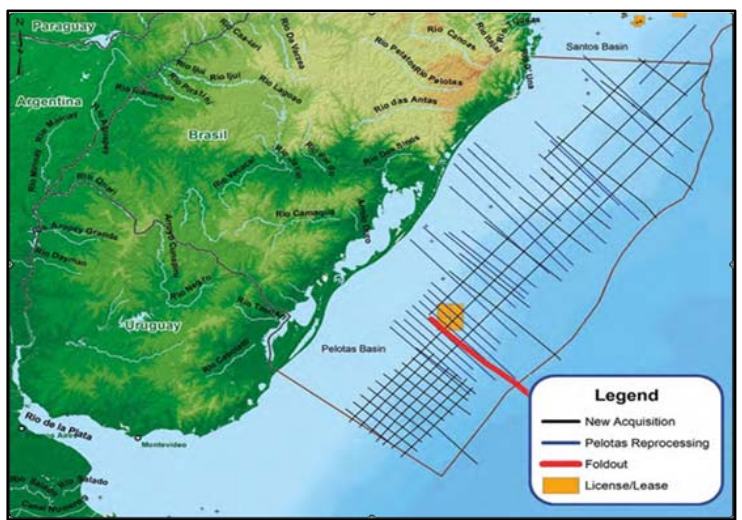

Figure 1 - Map showing the location of Spectrum 2D seismic data in the Pelotas Basin.

\section{Evidence for Hydrocarbons}

The new seismic data show that since the inception of rifting between South America and Africa (at $125 \mathrm{Ma}$ ), the mouths of paleo tributaries of the Rio de la Plata moved along the margin several times. The most recent depocenter comprises a four kilometer thick Tertiary siliciclastic sequence which displays a world-class direct hydrocarbon indicator in the form of a $40,000 \mathrm{~km}^{2}$ sheet of Bottom Simulating Reflectors (BSRs), which are confined inside the $3,000 \mathrm{~m}$ Tertiary isopach. The Tertiary delta has prograded over, and matured, a Paleocene source rock. Gas and condensate from this source rock subsequently migrated up through the sedimentary prism via abundant gas chimneys and plumes, to be trapped by the gas-water crystal phase change creating the BSR.

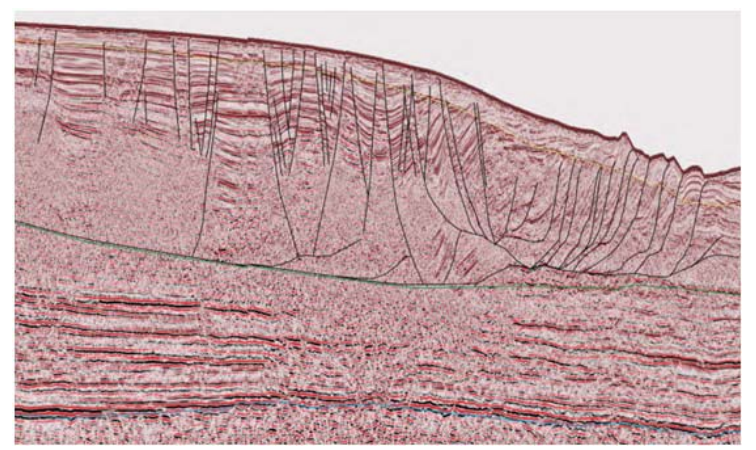

Figure 2 - Seismic section showing BSR (shown in red on Figure 1 map).

Additionally, numerous oil seeps detected by Synthetic Aperture radar and standard satellite imagery in the southern Pelotas Basin appear to define a linear feature, approximately coincident with the 500-800m isobaths. This suggests that oil, generated at depth below the Tertiary prism, is migrating up to the impermeable solid base of the hydrate until it reaches the up-dip extent of the BSR (ca. the 500-800m isobath). This oil is also trapped by stratigraphy or structure below the BSR, creating a shallow oil play within the Tertiary prism itself. 


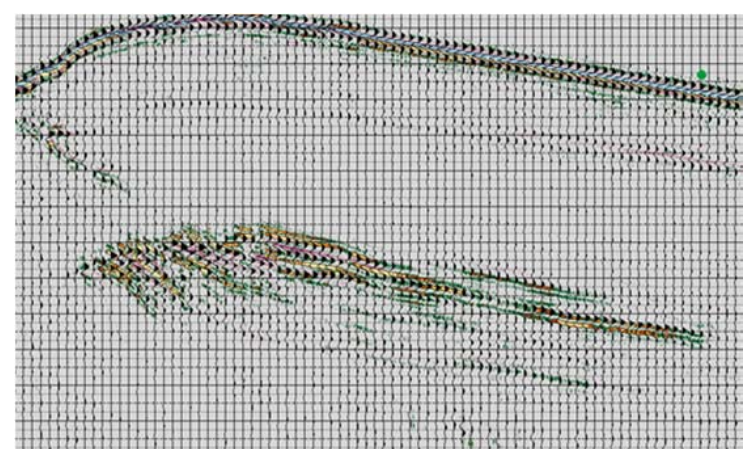

Figure 3 - Enhanced gradient AVO section showing liquid hydrocarbons trapped in porosity beneath the solid gas hydrate layer.

Preliminary AVO analysis indicates large accumulations of free hydrocarbons are trapped in porous intervals below the solid hydrate layer. Despite the abundant gas in these sequences it is the potential for large oil plays which is refocusing the attention of E\&P companies in the Pelotas Basin.

The BSR represents the base of a solid layer of gas hydrates, comprising frozen water molecules that form cages containing methane $\left(\mathrm{CH}_{4}\right)$, ethane $\left(\mathrm{C}_{2} \mathrm{H}_{6}\right)$ and propane $\left(\mathrm{C}_{3} \mathrm{H}_{8}\right)$ molecules trapped by freezing temperatures and high pressures. The pressure and temperature conditions necessary for the formation of hydrate crystals require an environment with water depths greater than $300 \mathrm{~m}$. The associated gas hydrates exist from approximately $100 \mathrm{~m}$ beneath the sea floor to as deep as 450m beneath the sea floor.

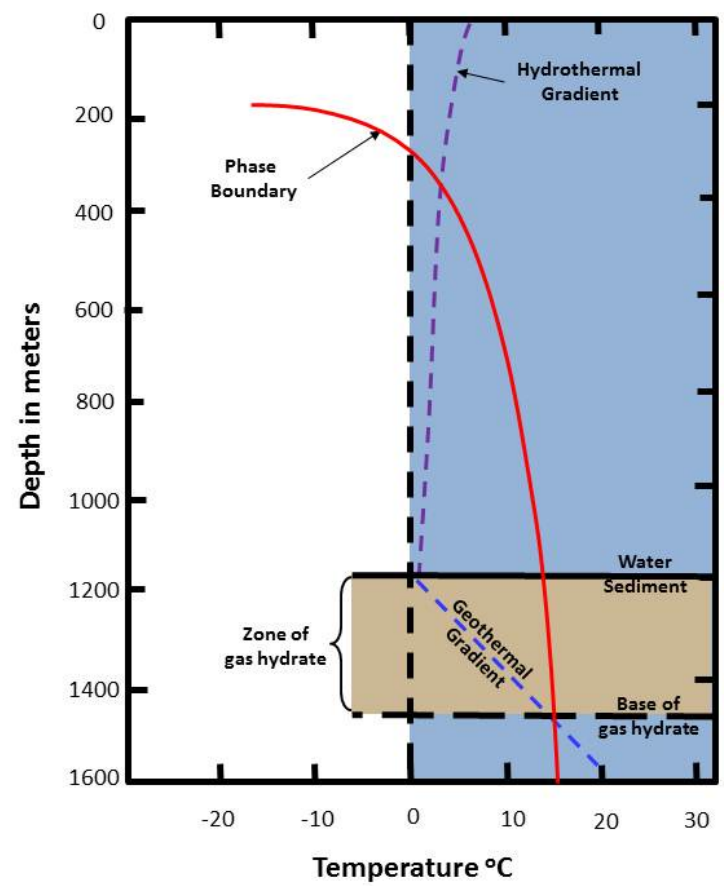

Figure 4 - Schematic diagram showing the hypothetical thermal gradient of stable gas hydrates for a location with a water depth of 1200 meters.

\section{Petroleum System}

The conjugate margin rift basins of West Africa and Brazil initially formed by east-west extension initiated during the early Cretaceous as the South American plate began to separate and rotate clockwise from Africa.

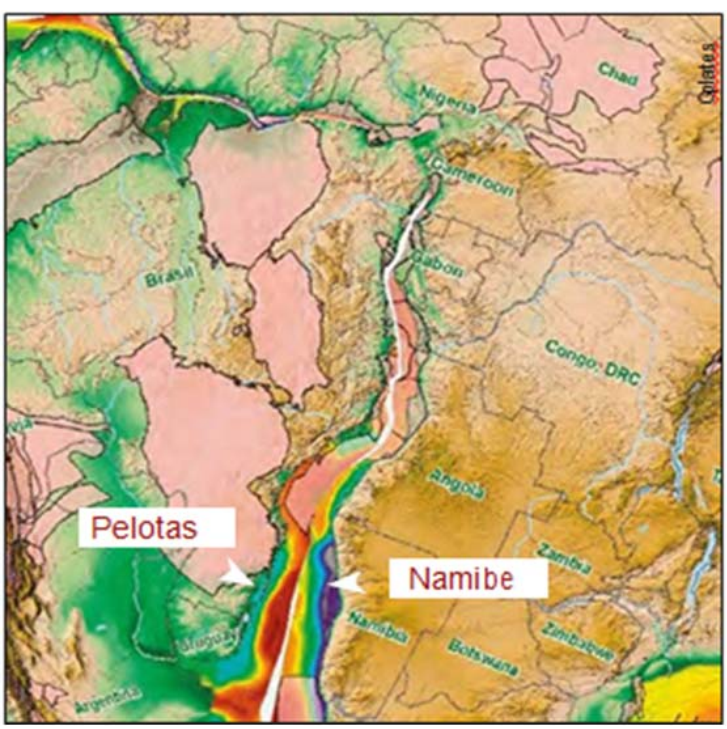

Figure 5 - Paleo-reconstruction with sediment thickness 125 $\mathrm{Ma}$, showing the original proximity of the Pelotas and Namibe Basins.

When the margins are reconstructed to their respective positions in the Albian it is informative to compare the respective margins for differences and similarities. A reconstruction with today's sediment thickness, joined where they may have been $125 \mathrm{Ma}$, shows the asymmetry from the Pelotas Basin to the conjugate Namibe Basin. This occurs because of large differences in the elevation of the terrains supplying a sediment source each to basin, and it is possible to correlate an Aptian-Albian sequence from Namibia to Pelotas. In mini-basins directly above the break-up unconformity, planar-bedded high amplitude AptianAlbian marine shales are correlated with units in the Namibe conjugate basin. In Namibia these shales are considered the primary deep water oil source for the light oil recovered from the Wingat-1 well. Additional source intervals in the Pelotas Basin include syn-rift Cretaceous lacustrine shales (Kudu, Orange River Basin analog), post-rift Aptian-Albian, CenomanianTuronian and Paleocene marine shales.

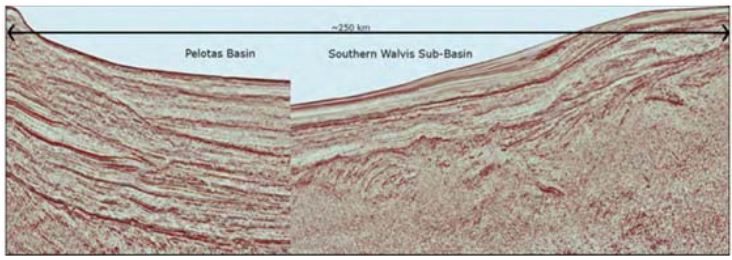

Figure 6 - Comparison sections at equal scale of the Pelotas and Namibia margins. 
Both the Pelotas and Namibian Basins are underlain by thickened high-density volcanic crust with an abundance of seaward dipping reflectors. Basin subsidence is controlled both by long-term post-rift thermal cooling and differential sediment loading and accommodation. The new seismic data in the area illustrates the Pelotas Basin received substantially more sediment than the Namibe Basin and consequently the basement is deeper.

In the Pelotas Basin, the prograding Tertiary wedge over the Paleocene source rock triggered a glide-plane detachment within the source rock, similar to the Niger Delta. Structural traps are developed within this gravitydriven structural complex along listric normal faults updip, and toe-thrust structures down-dip. The Orange River Basin in Namibia exhibits a similar, though older, feature with a deeper detachment on the CenomanianTuronian source rock.

Although few wells have penetrated the deep water section of either margin, the interpretation of the new seismic data suggests deltaic processes generated numerous potential plays. The supply of sediment from the shelf and delta to the post-rift thermally subsiding margin was subject to both global sea level change and locally controlled delta lobe switching. The new seismic data in the area indicates potential reservoir was deposited by mechanisms common to many passive margin mixed-source deltaic systems. Lowstand sands are interpreted within prograding siliciclastic wedges, in addition to lowstand slope fan sands. In the early Cretaceous, Aptian-Albian carbonates may have formed locally, creating a very exciting play interbedded with source rock. Additionally during the Lower and Upper Cretaceous and Tertiary, prograding units appear to have suffered shelf collapse and slope failure in parts of the basin, depositing turbidites, channel fill, and thick stacked slump sequences on the basin slope and floor.

\section{Exploration Opportunities}

Of the twelve wells drilled in the offshore Pelotas Basin to date, three were stratigraphic probes, seven were drilled on the shelf and two wells tested Tertiary prospects in deeper water, all of which were dry with oil shows. A more detailed examination of the seismic data indicates the deep water Pelotas Basin may contain more prospective targets than the shelf with reservoir and charge presenting the key technical risks.

There is considerable evidence of a large working petroleum system with a Paleocene source rock presently within the oil window, and correlation with the conjugate margin provides evidence of source rock in the Albian section which opens up a second deep water oil play. There are many good reasons to believe that the deep water Pelotas Basin warrants further exploration, inclusive of geoscience data acquisition and would make an excellent choice for blocks to be nominated in Brazil's upcoming Bid Round 13.

\section{References}

1. Abreu, Vitor, 1998, Geologic evolution of conjugate volcanic passive margins: Pelotas Basin (Brazil) and offshore Namibia (Africa). Implication for global sea level changes. Ph. D. Dissertation, Rice University, 648 p.

2. Contreras, Jorham, Rainer Zühlke, Scott Bowman, Thilo Bechstädt, 2010, Seismic stratigraphy and subsidence analysis of the southern Brazilian margin (Campos, Santos and Pelotas basins), Marine and Petroleum Geology, v. 27, p. 1952-1980.

3. Law, Carol, 2011, Northern Mozambique: True "Wildcat" Exploration in East Africa. Search and Discovery Article \#110157 (2011).

4. Seton, M, R.D. Müller, S. Zahirovic, C. Gaina, T. Torsvik, G. Shephard, A. Talsma, M. Gurnis, M. Turner, S. Maus, M. Chandler, 2012, Global continental and ocean basin reconstructions since $200 \mathrm{Ma}$, EarthScience Reviews 113, p. 212-270.

5. Marcelle-De Silva, Jill, Richard Dawe, 2011, Towards Commercial gas production from hydrate deposits, Energies, v. 4, p. 215-238. 